\title{
Elementary science teacher education in Korea: past, present, and future
}

Jisun Park@

Correspondence: jpark29@ewha.ac.

Elementary Education Department, College of Education, Ewha Womans University, Seoul, Republic of Korea

\begin{abstract}
This paper will present how the preservice elementary teacher education institutions have changed, what has become the qualification of teachers, and what is the hiring system. The development process of elementary teacher education institutions in Korea can be classified into four stages. The earliest national training for elementary school teachers started after World War II and continued both during and after the Korean War. From 1951 until 1961, elementary school teachers were required to have completed secondary school. However, from 1962 through to 1980, teachers needed to have completed high school and then be trained in two-year colleges. Finally, starting in 1982, elementary teachers began being trained in four-year universities. From this time, graduate schools began to be founded in national universities to focus on education and to both prepare preservice elementary school teachers to promote inservice teacher professionalism. Currently, there are 13 elementary teacher education institutions in Korea. This paper provides an overview about how science education courses are taught in these institutions and explains the pathways to becoming an elementary school teacher in Korea. Based on this historical review of the elementary teacher education system in Korea, I discuss future directions for continued research and development in primary education, especially in science.
\end{abstract}

Keywords: Elementary science teacher education, Korea, History

\section{Executive summary}

본 연구에서는 한국의 초등교원 양성기관의 변천 과정과 교사 자격 및 임용 체 계에 대해서 살펴보았다. 한국의 초등교원 양성기관의 변천은 고등학교 3년 과정의 사범학교 양성단계(1951년-1961년), 2년제 교육대학 양성단 계(1962-1920), 4년제 교육대학교 양성단계(1982년이후), 석사과정 이상의 교육대학원 설치 단계(1996년 이후)로 나누어 살펴보았다. 최근 한국에는 13 개의 초등교원 양성기관이 있으며, 각 양성기관에서 과학 교육이 어떻게 이루 어지고 있는지 개관하였다. 또한 교사 자격 부여 및 임용 체계에 대해 소개하 였다. 한국 초등교사 교육의 변천 과정의 개관을 바탕으로 한국 초등교원 양성 에 대한 시사점을 논하였다.

\section{Introduction}

Considering that the quality of education cannot be surpassed by the quality of the teacher, the improvement of the education depends on the improvement of the quality of the teacher who is directly in charge of the education in schools. Therefore, improving preservice teacher education, producing high quality teachers, and selecting

(c) The Author(s). 2019 Open Access This article is distributed under the terms of the Creative Commons Attribution 4.0 International License (http://creativecommons.org/licenses/by/4.0/), which permits unrestricted use, distribution, and reproduction in any medium, provided you give appropriate credit to the original author(s) and the source, provide a link to the Creative Commons license, and indicate if changes were made. 
competent teachers have been the most important tasks in education in Korea. This paper is intended to give a historical overview and future direction of preservice elementary teacher education focusing on science education. More specifically, this paper will present how the preservice elementary teacher education institutions have changed, what has become the qualification of teachers, and what is the hiring system.

\section{Historical overview of science teacher education in Korea}

The development process of elementary teacher training institutions in Korea can be classified into four stages (Kim et al. 2001). Following liberation from the Japanese at the end of World War II, the new Korean government established the first national education system designed to serve all students. From 1951 until 1961, elementary school teachers were required to have completed secondary school. However, from 1962 through to 1980, teachers needed to have completed high school and then be trained in two-year colleges. Finally, starting in 1982, elementary teachers began being trained in four-year universities. From this time, graduate schools began to be founded in national universities to focus on education and to both prepare preservice elementary school teachers to promote inservice teacher professionalism. In the sections that follow, I describe important developments in each time period.

High school-level teacher schools from 1951 to 1961

Since the independence from Japan in 1945 and the government was established, a large number of teachers were needed. Most teachers were Japanese before Korea's independence, but Japanese teachers returned to their home country after the war ended. Also, the need for basic education was emphasized after independence. For these reasons, training many elementary teachers in a short time period was an urgent challenge, and the elementary school teachers started to be trained in teacher schools at the high school level. There were 18 national teacher schools nationwide and these were threeyear high schools level schools for training elementary school teachers since 1951.

On the other hand, there was a case that the only private university has train elementary school teachers. In 1957, Ewha Womans University established an elementary education major at the College of Education. This is significant in that some teachers were trained in a four-year university compared to the most teachers were trained in high school-level teacher schools (Kim et al. 2001). Elementary education major at Ewha Womans University is now developed into elementary education department at Ewha Womans University. For this reason, elementary education department at Ewha Womans University, is currently the only private university that has an elementary education department in Korea.

At this time, as elementary school teachers were trained only to the high school-level, there was no big difference in curriculum between schools for training elementary teachers and the curriculum completed by all graduates of general high school (Kim and An 1994). Therefore, preservice teachers at that time learned science as part of the high school curriculum and it was not specialized for elementary science education. The only difference that students seeking to become teachers learned different from general high school students was a subject called "education". The Table 1 shows the curriculum and class hours of a teacher education coursework in the early 1950s (Park 1959:65). 
Table 1 An example of the curriculum at high school-level teacher school in 1950's

\begin{tabular}{llll}
\hline Subject & Class hours & & \\
\cline { 2 - 4 } & $1^{\text {st }}$ year & $2^{\text {nd }}$ year & $3^{\text {rd }}$ year \\
\hline Science & 128 & 128 & 96 \\
Korean & 96 & 96 & 72 \\
Social science & 96 & 96 & 72 \\
Math & 96 & 96 & 72 \\
Physical education & 96 & 96 & 48 \\
Music & 96 & 96 & 72 \\
Art & 128 & 128 & 72 \\
Home economics & 96 & 96 & $48-96$ \\
Foreign language & $64-128$ & $64-128$ & 168 \\
Education & 128 & 128 & \\
\hline
\end{tabular}

Two-year college of education from 1962 to 1980

From the 1960s, elementary school teachers were trained at the university level, but in two-year colleges. All secondary school teacher programs were changed into two-year colleges in 1962. These two-year teacher colleges were named "national college of education" and they had three main courses: general courses, education courses, and selective courses. General courses dealt with the content knowledge of each subject that is intended to teach in the elementary school curriculum. Education courses were for improving the teacher professionalism of each subject. The selective course was a kind of intensive education course. In general courses, various subjects including science were taught and 6 hours to learn science were allocated per week. In education courses, 16 hours were allocated to the course called "teaching methods of each subjects".

By 1970, sixteen two-year national colleges of education had been established, which led the oversupply of elementary teachers. Eventually, five two-year national colleges of education were converted into general universities in 1977 and only 11 of the original two-year national colleges of education were left. In addition to these two-year colleges of education, Ewha Womans University kept their course and became a four-year university.

\section{Four-year university of education from 1981 to present}

In the 1980s, the two-year national colleges of education were reorganized into fouryear universities. In 1984, Korea National University of Education was founded for collectively preparing kindergarten, elementary and secondary school teachers. Therefore, since 1984, there have been 13 institutions that prepare elementary school teachers including 11 national universities of education, an elementary education department at Ewha Womans University and an elementary education department at Korea National University of Education.

As the two-year colleges of education were converted into four-year universities of education, the credits that pre-service teachers should take were increased. For instance, 150 credits that students should take for graduation at the four-year university of education in 1980's compared to 110 the credits for the two-year college. Also their curriculum was reorganized into three: liberal arts course, major course, and advanced 
major course. Major courses can be divided into education foundation and subject based education. All the university of education has only one major, which is elementary education. However, as elementary teachers teach all the subjects, each university of education run advanced major course and students should take certain credits for them. For instance, when a student who enrolled the university of education and she/he should choose one subject department for their advanced major. If she/he chooses science education, then she/he should take advanced science education major course in addition to liberal arts and major course. If other students choose other advanced major such as music or math, they do not need to take advanced science education major coursework and instead they should take advanced coursework in their own major.

\section{Graduate schools and professional development from 1996 to present}

The elementary school teachers have been trained through four-year university courses at undergraduate level. In 1990's, the need for graduate schools in national universities of education raised to improve teacher professionalism. In 1996, the graduate schools of education were established in ten national universities of education but Jeju National University of Education. In case of graduate school of education in Jeju National University of Education was established in 2000. Compared to national universities of education, Ewha Womans University has graduate school of education since 1967 and elementary education major was newly established separating from education major in 1995 with other national university of education.

The function of graduate schools of education in national universities of education was different from the graduate school of education at the secondary level. Secondary school teachers can be trained from either the undergraduate level or graduate level. This means that some graduate schools for secondary education at colleges of education function to prepare secondary pre-service teachers and professional development of in-service teachers. This is because they can confer teacher certificates after students complete teacher education programs at the graduate school level. Contrary to secondary teacher education, elementary teacher education is only taught at these designated four-year universities and certificates for elementary teachers can be issued for completing these undergraduate courses only. Therefore, graduate schools for elementary education only function as a professional development for in-service teachers.

These graduate schools of education in national universities of education only offer master degree courses. In 2013, two national universities of education, Seoul National University of Education and Gyeongin National University of Education, got permission to establish an Ed.D program in their graduate school of education. Again, compared to these national universities of education, Ewha Womans University has had Ph.D. courses for elementary education since 1991.

\section{Current state of elementary teacher education in Korea}

Currently elementary teachers were prepared in 12 national universities and one private university at undergraduate level. Here we will explain the current curriculum in these designated universities for elementary education and especially focusing on how they make an effort to improve teacher professionalism on science education. Also we will 
explain how national teacher employment test is administered especially in science. Lastly, how teachers teach science in elementary schools is roughly explained.

\section{Current curriculum for preparing elementary teachers}

There have been up to 13 institutions that prepare elementary school teachers including 11 national universities of education, an elementary education department at Korea National University of Education, and an elementary education department at Ewha Womans University. As shown in Table 2, national universities of education are college-sized universities and all students major in elementary education. However, students are divided into several departments according to their majors. There were 1546 students enrolled in April 2019, which means that approximately 385 students enrolled as freshmen every year. These 385 students can be divided into 13 intensive courses and each intensive course will have approximately 30 students per year. In the case of Korea National University of Education, there are three colleges and a department of elementary education in the first college (See Fig. 1). Unlike other national university of education, Korea National University of Education consists of an early childhood education department, an elementary education department, and other secondary level departments. There were 503 students in April 2018 in the elementary department at Korea National University of Education, which means that approximately 125 students entered as freshmen. As Korea National University of Education has 11 intensive courses, each intensive course will have 10-13 students. In the case of Ewha Womans University, there were approximately 140 students in total in the elementary education department and each year 39-41 students enter as freshmen.

As mentioned in previous chapter, elementary teachers are prepared in four-year level universities and teacher certificate is issued after completing curriculum of 130150 credits without having test. For teacher certificate, more than 50 credits of major course and more than 22 credits of pedagogy course need to be completed. Table 3 shows the credit hours in Seoul National University of Education, Elementary Education Department at Korea National Universities of Education, and elementary department at Ewha Womans University. Science education is mostly handled in content specific pedagogy. In case of Seoul National University of Education, most of students will take at least 7 credits about science education and students who choose their intensive course as science education will take 20 credits more about science education. In case of Korea National University of Education, most students will take 4 credits and students who choose science education as their intensive course will take 21 more

Table 2 Size of Seoul National University of Education, Korea National University of Education, and Ewha Womans University

\begin{tabular}{|c|c|c|c|}
\hline & $\begin{array}{l}\text { Seoul National } \\
\text { University of } \\
\text { Education }\end{array}$ & $\begin{array}{l}\text { Elementary Education Department at } \\
\text { Korea National Universities of } \\
\text { Education }\end{array}$ & $\begin{array}{l}\text { Elementary Education } \\
\text { Department at Ewha Womans } \\
\text { University }\end{array}$ \\
\hline \multirow[t]{2}{*}{$\begin{array}{l}\text { The number of } \\
\text { students in total }\end{array}$} & $\begin{array}{l}1546 \text { (in April } \\
2019)\end{array}$ & 503 (in April 2018) & 167 (in April 2019) \\
\hline & $\begin{array}{l}\text { Approx. } 385 \text { per } \\
\text { year }\end{array}$ & Approx. 125 per year & Approx. 41 per year \\
\hline $\begin{array}{l}\text { The number of } \\
\text { advanced } \\
\text { courses }\end{array}$ & 13 & 11 & - \\
\hline
\end{tabular}




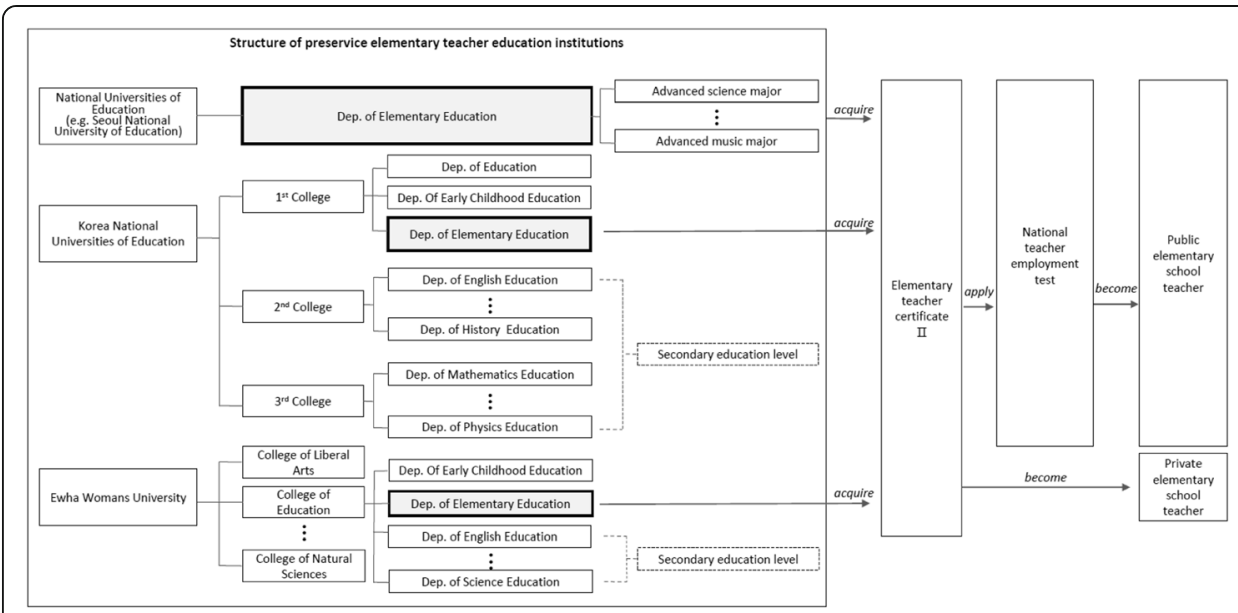

Fig. 1 Pathways to becoming elementary teachers in Korea

credits about science education. In case of Ewha Womans University, most students will take 3-6 credits about science education, as there is no intensive course. According to Kim et al. (2011), 13 universities that prepare elementary teachers provide an average of 4.9 course credit hours for developing science teaching and learning professionalism. This means that students graduate and become a teacher after taking 2-3 courses about science education considering that one course usually take three credits.

As elementary teachers should teach all subjects, including science in schools, curriculum for pre-service teachers also includes all subjects. Therefore, the allocating course and time for science education is limited and a large amount of pedagogical knowledge for science needs to be dealt with very much effectively in a short period of time. Although we all agree that it is very limited time to build the expertise in teaching and learning science, it is practically difficult to increase credits only for science education. However, many elementary teachers in schools are struggling to teach science and they show relatively low science teaching efficacy belief (Ji and Park 2016).

Compared to 4-week of practicum in secondary education, practicum is regarded important in the curriculum of elementary education. As shown in the Table 3, Seoul

Table 3 Credit hours of Seoul National University of Education, Korea National University of Education, and Ewha Womans University (as of year 2020)

\begin{tabular}{|c|c|c|c|}
\hline & $\begin{array}{l}\text { Seoul National } \\
\text { University of } \\
\text { Education }\end{array}$ & $\begin{array}{l}\text { Elementary Education } \\
\text { Department at Korea National } \\
\text { Universities of Education }\end{array}$ & $\begin{array}{l}\text { Elementary Education } \\
\text { Department at Ewha } \\
\text { Womans University }\end{array}$ \\
\hline Liberal arts course & 34 & 23 & 35 \\
\hline \multicolumn{4}{|l|}{ Pedagogy } \\
\hline Pedagogy theories & 18 & 18 & 18 \\
\hline Practicum & 4 (9 weeks) & 4 (9 weeks) & 5 (12 weeks) \\
\hline Educational volunteer program & $\mathrm{P} / \mathrm{F}$ & 2 & $\mathrm{P} / \mathrm{F}$ \\
\hline \multicolumn{4}{|l|}{ Major } \\
\hline $\begin{array}{l}\text { Content specific pedagogy and } \\
\text { creative experiential activity } \\
\text { (Science education course) }\end{array}$ & $64(7)$ & $70(4)$ & $57-77(3-6)$ \\
\hline Intensive course & 20 & 21 & - \\
\hline Total & 140 & 140 & 135 \\
\hline
\end{tabular}


National University of Education has a 9-week practicum and the elementary education department at Ewha Womans University has a 12-week practicum. In the case of Seoul National University of Education and Korea National University of Education, a oneweek observation is offered in the spring term of the second year and two-week practicum in the fall term of the second year. Also two-week practicums are provided in each the spring and fall term of the third year. Lastly another two-week practicum is provided in the spring term of the fourth year. In case of elementary education department at Ewha Womans University, the first 4-week practicum is offered just after the spring term of second year. This first 4-week practicum is called as "observation and teaching practicum in public schools" and pre-service teachers are to watch mentor teachers' lessons and they try to teach a lesson in collaboration with mentor teacher or peers. This process is for making pre-service teacher to get used to teaching and learning in schools. The second 4-week practicum is offered just after the spring term of third year. This second 4-week practicum is called as "class management practicum in public schools". During this practicum, pre-service teachers are to teach more lessons than they were second year and they also learn how to manage the class as a homeroom teacher. Lastly, the third 4-week practicum is offered in the spring term of the fourth year. This last 4-week practicum is called as "comprehensive practicum in private school". This practicum is offered in the Ewha Womans University elementary school. This elementary school is private school and affiliated school of university. Pre-service teachers teach more lesson than last two practicums and also experience a whole day as a homeroom teacher.

These examples show that each practicum is run in stages and each stage provides gradual development in teacher practices. Although practicum is well organized in elementary pre-service teacher education, it is still doubtful that it is enough time for teachers to develop pedagogical strategies and confidence in teaching science (Kim et al. 2018). Pre-service teachers usually get one or two chances to teach science or a few of them sometime get no chance to teach science in their practicum as they have to handle all the subject.

\section{Elementary teacher certificate and national teacher employment test}

According to current statistics of 2019, there are a total of 6,087 elementary schools in Korea, and 188,582 elementary school teachers work at these elementary schools. Public schools account for $98.78 \%$ of all schools and only $1.22 \%$ are private schools (Korean Educational Development Institute 2019). Teachers in public schools work as teachers under the teacher employment test, which is led by the government in cooperation with state or municipal office of education. The qualification for taking the teacher employment test is for those who have an elementary teacher certificate II or I.

Elementary teacher certificate II is currently granted in 11 national universities of education, Korea National University of Education, and the elementary education department at Ewha Womans University (See Fig. 1). Among universities granting elementary teacher certificates, Ewha Womans University is the only private university with an elementary education. Thirteen universities including Ewha Womans University are required to grant the elementary teacher certificate II to those who have completed the national teacher education curriculum. A certificate is issued to those who 
have completed a set of determined courses at a teacher education university, even without having a qualification test. This means that the current elementary teacher qualification system seeks to enhance the quality of education by focusing on process of teacher education rather than improving the quality of teachers by examination (Song et al. 2000).

Contrary to elementary teacher education, preservice secondary teacher education has various pathways to get teacher certification. One is the teacher education program in the college of education at the undergraduate level. Another is a teacher education program, which requires students to take more teaching professional courses in addition to the coursework for their major. The other is teacher education program at graduate level. For instance, there are three ways to become science teacher at secondary level in Korea. One is graduating science education department at 4-year undergraduate level, taking teaching professional courses with majoring natural science such as physics, chemistry, biology, and earth science. The other is graduating science education department at 2-year graduate level.

In summary, the preservice elementary teacher education in Korea is run by 13 designated institutions and is led by the government. This is why national universities of education for elementary teacher education were established in each province in order to provide responsible education for primary education as a basic education. As mentioned earlier, those who have graduated from Ewha Womans University or other national universities of education would automatically obtain an elementary teacher certificate II and they can become public school teachers when they pass the national teacher employment test.

According to the national policy of teacher supply and demand, which is designed to stably control the supply and demand of excellent teachers, the limited number of teachers is being supplied to the schools by the national teacher employment test (Shin 2009). In other words, the Korean teacher employment system is a competitive test system through selection. This employment test is administered by the Korea Institute for Curriculum and Evaluation and each Metropolitan and Provincial Office of Education. For example, the Seoul Metropolitan Office of Education counts the number of teachers needed for 2019 and later than 2019, announces the test with the number of teacher candidate they need in mid-2018, conducts the test in the November and December, and announces those who have been passed text in January 2019. Those who pass the employment test will be working at the elementary school at Seoul, and school to work is given by the Seoul Metropolitan Office of Education. In this way, teachers who work in each province go through separate selection process in each province, but the first selection process is led by the government -funded research institution, Korea Institute for Curriculum and Evaluation. Each Metropolitan and Provincial Office of Education conducts the second selection process. All teachers who passed the national teacher employment test becomes national officials.

Given the importance of this national employment test, science items in teacher employment test shows how professionalism in elementary science teaching is assessed. According to Park (2019), the science items in elementary teacher employment test include educational situation to evaluate whether test takers can apply their knowledge into educational situation. It also has been essay type items or short answer items since 2013 rather than multiple choice items. However, essay type items have only a function 
of asking for more detailed content than the short answer items can ask. It is not ideal to use essay items to assess teacher ideas about how to teach science. This is related to the content of assessment items. Assessment items about scientific knowledge were dominant such as scientific concept and scientific inquiry process skills. Despite only a few questions can be asked in elementary teacher employment test as all the subject knowledge needs to be assess, it is necessary to make an effort to assess teacher knowledge in science teaching in various ways.

\section{Future direction for science teacher education in Korea}

Modern society is rapidly changing and expanding its knowledge of the natural world and knowledge of technology as fast as new knowledge is formed. This change in knowledge has had many effects on what teachers need to understand about students and what they need to teach them. In particular, elementary school teachers should be able to raise scientific literacy for children as citizens to live in the 21st century. Therefore, elementary teacher education programs should develop the ability to meet these responsibilities for pre-service elementary teachers.

In previous sections, we could see that a quantitative development has been made in elementary teacher education programs as evidenced by increasing the training period from two to four years. Also, graduate schools were established in addition to undergraduate level courses. However, now we need to rethink how to improve the qualitative development for how pre-service teachers are prepared to teach, especially in the area of science teaching.

In 1998, the National Association of Teachers of Science (NSTA) made standards for science teacher preparation. This included ten broad standards that show the ability of all pre-service teachers at the elementary and secondary level to be equipped in teacher education programs. Several changes have been made since 1998 and NSTA newly announced 2020 standards for science teacher preparation.

In Korea, we have no such standards for science teacher preparation, especially at the elementary levels. At the secondary level, however, there have been similar attempts. In 2008, the Korea Institute of Curriculum and Evaluation suggested the introduction of qualification criteria for science teachers including physics teachers, chemistry teachers, earth science teachers, biology teachers, and general science teachers. However, this initiative has been limited because it simply established the scope of the teacher employment test rather than actually acting to provide direction for guiding the implementation of teacher education programs at the university level.

To teach science well in schools requires specialized knowledge and skills. However, since elementary school teachers are required to teach all subjects, no subject can be neglected in the pre-service teacher education program. For this reason, elementary teachers have a lot of difficulties in improving their subject matter, that is, their expertise in science. Previous studies reported that many elementary teachers and preservice elementary teachers have a relatively low self-efficacy in teaching science compared to other subjects and this resulted in teaching less science as possible (Bencze and Hodson 1999; Buss 2010; Petersen and Treagust 2014). In recent years, many studies were conducted to enhance self-efficacy in teaching science in preservice teacher education programs by improving science methods courses or providing successful experience in teaching science (Palmer et al. 2015). As mentioned in previous sections, the pre- 
service elementary teacher education programs in Korea spend an average of 4.9 hours on science education, and the direction and content of education depends on the capacity of individual instructors. Pre-service elementary teachers acquire most of the science education knowledge associated with elementary science subjects from teacher education programs. In addition, science education courses in the teacher education program provide a model of what science content they should teach and how to teach science when they become teachers. Therefore, it is important that what the teacher education program for science education teaches and what is aimed for, and it is necessary to guide teacher education standards.

\section{Abbreviation \\ MOE: Ministry of Education}

Acknowledgements

Not applicable.

\section{Author's contributions}

The author read and approved the final manuscript.

\section{Author's information}

Jisun Park is an assistant professor at Ewha Womans University in the Elementary Education Department. Her research focus is on the teaching and learning of science at the elementary level.

Funding

Not applicable.

\section{Availability of data and materials}

All data discussed is available from sources cited in the paper. The data sets can be made available from the corresponding author on reasonable request.

\section{Ethics approval and consent to participate}

The data collected from this article did not involve human subjects so no human subjects approval was necessary.

\section{Consent for publication}

I (the author) agree that this article will be published in the APSE journal.

\section{Competing interests}

The author declares that she has no competing interests.

Received: 30 August 2019 Accepted: 13 November 2019

Published online: 27 December 2019

\section{References}

Bencze, L., \& Hodson, D. (1999). Changing practice by changing practice: Toward more authentic science and science curriculum development. Journal of Research in Science Teaching, 36, 521-539.

Buss, R. R. (2010). Efficacy for teaching primary science and mathematics compared to other content. School Science and Mathematics, 110(6), 290-297.

Ji, S.-M., \& Park, J.-K. (2016). The beginning elementary school teachers' difficulties to suffer in the science classes from the perspective of content knowledge and teaching method. Journal of Science Education, 40(2), 116-130.

Kim, M., Yoon, H.-G., \& Lee, M.-K. (2018). Progress and challenges of elementary science education in Korea. In Y.-J. Lee \& J. Tan (Eds.), Primary science education in East Asia, contemporary trends and issues in science education. New York: Springer

Kim, M.-H., Cho, M., \& Kim, S.-W. (2011). A study of the science curriculum in elementary teacher education and in-service teachers' perceptions of the curriculum. Journal of Research in Curriculum Instruction, 15(2), 473-492.

Kim, S. H., Jeon, S. K., \& Lee, M. J. (2001). The problem of elementary teacher education system and its improvement plan. The Journal of Elementary Education, 14(3), 89-116.

Kim, Y., \& An, G. (1994). History of elementary teacher education in modern Korea. Seongnam: The Academy of Korean Studies.

Korean Educational Development Institute (KEDI). (2019). 2019 Korean Educational Statistics Service. Retrieved from https:// kess.kedi.re.kr/index

Palmer, D., Dixon, J., \& Archer, J. (2015). Changes in science teaching self-efficacy among primary teacher education students. Australian Journal of Teacher Education, 40(12), 27-40.

Park, J. (2019). Analysis of science items in elementary teacher employment tests: focused on questionnaires from 2001 to 2018. Journal of Learner-Centered Curriculum and Instruction, 19(3), 647-661.

Park, S. (1959). History of Education in Korea. Seoul: Korean Education Association.

Petersen, J. E., \& Treagust, D. F. (2014). School and University Partnerships: The Role of Teacher Education Institutions and Primary Schools in the Development of Preservice Teachers' Science Teaching Efficacy. Australian Journal of Teacher Education, 39(9), 153-167. 
Shin, H.-S. (2009). Policy directions and strategies to reform pre-service education of teachers. The Journal of Korean Education, 36(3), 53-78.

Song, G.-Y., Lee, C.-C., \& Lee, W. H. (2000). School education system and teacher qualification system in the $21^{\text {st }}$ century. The Journal of Korean Teacher Education, 17(1), 93-118.

Publisher's Note

Springer Nature remains neutral with regard to jurisdictional claims in published maps and institutional affiliations.

Submit your manuscript to a SpringerOpen ${ }^{0}$ journal and benefit from:

- Convenient online submission

- Rigorous peer review

- Open access: articles freely available online

- High visibility within the field

- Retaining the copyright to your article

Submit your next manuscript at $\boldsymbol{\nabla}$ springeropen.com 